\title{
PENGEMBANGAN BAHAN AJAR BERBASIS MULTIMEDIA INTERAKTIF DALAM MENINGKATKAN MINAT BELAJARMATEMATIKA SISWA
}

\author{
Rizqi Nuritno ${ }^{1}$, Hendri Raharjo ${ }^{2}$, Widodo Winarso ${ }^{3}$ \\ Tadris Matematika \\ Institut Agama Islam Negeri (IAIN) Syekh Nurjati Cirebon \\ E-mail: rizqinuritno@gmail.com ${ }^{1)}$, hendri.iainsnj@gmail.com²),widodoiain@gmail.com ${ }^{3)}$
}

\begin{abstract}
This research is a form of interactive multimedia development as a resource that aims to: 1) Develop Interactive Multimedia Learning Material and Beam Cube; 2) Determine the feasibility of Cube Interactive Multimedia Learning Material and Beam; 3) Increasing interest in learning math using the Interactive Multimedia Learning Material and Beam Cube. This research method is the Research and Development $(R \& D)$, adapted from ADDIE development model, with the following steps: 1) Analysis,2) Design,3) Development,4) Implementation5) Evaluation.Validation is done by two people matter experts and two experts media. Teaching materials developed tested to 5 learners VIII class A and 31 learners in class VIII B of SMP Negeri 12 Cirebon. Feasibility level Interactive Multimedia-Based Instructional Materials and Beam Cube based assessment: 1) Matter Experts obtained an average value of 4.2 which is included in the category of Good, 2) Expert Media obtained an average value of 4.26 are included in the category of Very Good, 3) learners field trials obtained an average value of 4.26 are included in the category of Very Good. Thus the Interactive Multimedia-Based Instructional Materials and Beam Cube is good and fit for use as teaching material. Based on the analysis Interest in Learning students before and after the use of the Interactive Multimedia-Based Instructional Materials and Beam Cube, obtained by $N$-gain of 0.405 which is included in the category of Medium of the total score early 2026 into 2521. In the test paired t test obtained t count equal to -16.619 with sig, 0,000 showed significant measurement so that the conclusion is the development of Interactive Multimedia-Based Instructional Materials and Beam Cube can improve Students Interest in Learning Mathematics.
\end{abstract}

Keywords: Multimedia Interactive, Learning Interests, ADDIE..

\section{PENDAHULUAN}

Salah satu komponen penting dalam pendidikan adalah guru, guru sebagai perencana pembelajaran dituntut untuk mampu merancang pembelajaran dengan memanfaatkan berbagai jenis media dan sumber belajar yang sesuai agar proses pembelajaran berlangsung secara efektif dan efisien.Proses pembelajaran matematika kebanyakan masih belum menunjukkan hasil yang memuaskan, upaya guru kearah peningkatan kualitas proses belajar mengajar belum optimal, metode, pendekatan dan evaluasi yang dikuasai guru belum beranjak dari pola tradisional, dan hal ini berdampak negatif tehadap daya serap siswa yang ternyata masih tetap lemah.

Kegiatan belajar mengajar yang konvensional dengan metode ceramah merupakan cara yang paling aman untuk mengejar pencapaian target pembelajaran. Padahal pencapaian kompetensi sebagaimana tertuang dalam Standar Kompetensi dan Kompetensi Dasar memerlukan metode dan pendekatan aktif learning yang bervariasi guna meningkatkan kemampuan siswa menguasai suatu kompetensi (Depdiknas, 2007: 17)

Sesuai dengan Peraturan Pemerintah (PP) nomor 19 tahun 2005, mengisyaratkan bahwa guru diharapkan mengembangkan materi pembelajaran, yang kemudian dipertegas melalui Peraturan Mentri Pendidikan Nasional (Permendiknas) nomer 41 tahun 2007 tentang standar proses, yang antara lain mengatur tentang perencanaan proses pembelajaran yang mensyaratkan bagi pendidik pada satuan pendidikan untuk mengembangkan rencana pelaksanaan pembelajaran (RPP). Salah satu elemen pada RPP adalah sumber belajar, dengan demikian guru diharapkan untuk mengembangkan bahan ajar sebagai salah satu sumber belajar. Oleh karena itu, sumber belajar yang digunakan harus efektif dan selektif sesuai dengan pokok bahasan yang diajarkan. Pengembangan bahan ajar diharapkan dapat membantu memecahkan permasalahan dalam pembelajaran.

Pada saat penyampaian materi pelajaran terkadang ada materi yang sulit dipahami jika hanya menggunakan buku cetak. Hal ini disebabkan karena buku 
pelajaran matematika yang ada dipasaran sebagian besar hanya berisi rumus-rumus dan soal-soal latihan serta menggunakan bahasa tingkat tinggi yang menjadikan siswa malas membaca dan berakibat pada sulitnya siswa dalam memahami materi yang disampaikan oleh guru. Sehingga untuk membantu siswa memahami materi, guru membutuhkan bahan ajar lain

Dalam studi pendahuluan yang dilakukan oleh peneliti pada tahun pelajaran 2016/2017 di SMP N 12 Kota Cirebon bahan ajar yang sering digunakan oleh guru matematika adalah bahan ajar cetak seperti buku paket. Sedangkan buku paket itu juga merupakan buku yang banyak beredar di pasaran, kebanyakan mengguakan bahasa yang tinggi sehingga siswa kurang mengerti dengan isi materinya. Bahan ajar non cetak seperti bahan ajar yang berbasis multimedia interaktif sangat jarang digunakan pada saat pembelajaran.

Selama ini bahan ajar cetak yang digunakan berupa buku-buku pelajaran matematika masih belum bisa menarik minat siswa dalam pembelajaran matematika. Seiring berkembangnya ilmu pengetahuan dan teknologi tentu membawa perubahan yang cukup besar bagi dunia pendidikan, maka mengembangkan bahan ajar berbasis multimedia interaktif untuk pembelajaran matematika menjadi salah satu solusi dalam masalah yang ditemukan. Dengan adanya pengembangan bahan ajar berbasis multimedia interaktif untukpembelajaran ini diharapkan peserta didik tidak akan merasa jenuh lagi dalam proses pembelajaran matematika berlangsung dan mempermudah peserta didik dalam memahami konsep-konsep matematika.

Selain itu diharapkan peserta didik dapat memahami materi yang disampaikan oleh seorang guru sehingga minat belajar peserta didik akan lebih baik setelah belajar menggunakan bahan ajar berbasis multimedia interaktif yang telah dikembangkan.

Salah satu aplikasi yang digunakan untuk pengembangan bahan ajar berbasis multimedia interaktif adalah Adobe Flash.
Adobe Flash merupakan aplikasi yang digunakan untuk melakukan design dan membangun perangkat presentasi, publikasi, atau aplikasi lainnya yang membutuhkan ketersediaan sarana interaksi dengan penggunanya. Aplikasi Adobe Flash merupakan program yang paling fleksibel untuk membuat animasi sehingga banyak yang menggunakan program tersebut, dengan menggunakan Adobe Flash ini diharapkan mampu membuat bahan ajar berbasis multimedia yang interaktif dan materi yang disampaikan dapat direspon positif oleh peserta didik.

Salah satu penelitian yang dilakukan oleh Resti Cahyaningsih (2016) tentang Pengembangan Bahan Ajar Berbasis Multimedia Interaktif DalamMeningkatkan Motivasi Belajar Pendidikan Agama Islam (PAI) Pada Siswa Kelas VII Di SMP Islam AlAzhar Tulungagung menghasilkan kesimpulan bahwa bahan ajar yang dikembangkan dapat meningkatkan motivasi belajar Pendidikan Agama Islam (PAI) di SMP Islam Al-Azhar Tulungagung berdasarkan hasil uji coba, yaitu dengan skor rata-rata 4,6 yang termasuk berkategori baik.

Walaupun pada penelitian tersebut subjek yang diteliti adalah untuk pembelajaran Pendidikan Agama Islam (PAI) serta efektifitasnya untuk meningkatkan motivasi belajar siswa namun setidaknya memberikan gambaran bahwa model pembelajaran berbasis multimedia interaktif layak dan lebih efektif dibanding model pembelajaran konvensional. Permasalahannya adalah bagaimana jika model pembelajaran berbasis multimedia interaktif digunakan untuk mata pelajaran matematika dan untuk mengetahui minat belajar siswa, apakah akan menunjukkan hasil yang sama dengan penggunaan multimedia interaktif pada pembelajaran PAI yang efeknya untuk meningkatkan motivasi belajar siswa. Pada kenyataannya bahan ajar berbasis multimedia interaktif untuk pelajaran matematika sudah banyak tersedia, namun belum banyak yang melakukan penelitian untuk meningkatkan minat belajar siswanya terutama yang 
membahas tentang materi pokok kubus dan balok.

Sehingga sebelum menguji efektivitas bahan ajar berbasis multimedia interaktif dalam pembelajaran matematika, langkah pertama yang harus dilakukan adalah menyediakan atau mengembangkan bahan ajar berbasis multimedia interaktif. Selanjutnya setelah bahan ajar dinyatakan layak, maka baru bisa diuji seberapa besar efektivitasnya terhadap minat belajar siswa.

Berdasarkan uraian di atas, peneliti tertarik untuk melakukan penelitian dengan judul "Pengembangan Bahan Ajar Berbasis Multimedia Interaktif Dalam Meningkatkan Minat Belajar Matematika Siswa”.

\section{LANDASAN TEORI}

Menurut National Center For Vocational Education Research Ltd / National Center For Competency Training ada 2 pengertian bahan ajar yaitu: a) Bahan ajar merupakan informasi, alat dan teks yang diperlukan guru atau instruktur untuk perencanaan dan penelaahan implementasi pembelajaran. b). Bahan ajar adalah segala bentuk bahan yang digunakan untuk membantu guru atau instruktur dalam melaksanakan kegiatan belajar mengajar di kelas. Bahan yang dimaksud bisa berupa bahan tertulis maupun bahan tidak tertulis (Majid, 2009:173-174).

Ika Lestari berpendapat bahwa bahan ajar merupakan seperangkat sarana atau alat pembelajaran yang berisikan materi pembelajaran, metode, batasanbatasan dan cara mengevaluasi yang didesain sistematis dan menarik dalam rangka mencapai tujuan yang diharapkan, yaitu mencapai kompetensi atau subkompetensi dengan segala kompleksitasnya (Lestari, 2013: 1).

Sedangkan menurut I'anah dalam Raharjo (2014: 125) bahan ajar adalah bahan atau materi pelajaran yang disusun secara sistematis baik tertulis maupun tidak tertulis yang digunakan oleh guru dalam pembelajaran di kelas untuk menciptakan suasana/lingkungan pembelajaran yang memungkinkan siswa berminat untuk belajar sehingga mencapai standar kompetensi yang telah ditentukan.
Dengan demikian bahan ajar pada hakekatnya penyampaian materi/bahan yang disusun secara sistematis baik tertulis atau tidak tertulis untuk mencapai tujuan kompetensi yang diharapkan, dalam penyampaiannya diperlukan guru atau instruktur untuk perencanaan dan penelaahan implementasi pembelajaran jika dibutuhkan oleh siswa.

Menurut Prastowo (2014: 147-148) dari segi bentuknya, bahan ajar dibedakan menjadi empat macam, yaitu:

a. Bahan ajar cetak (printed) adalah sejumlah bahan yang disiapkan dalam kertas, yang dapat berfungsi untuk keperluan pembelajaran atau penyampaian informasi. Contohnya handout, buku, modul, lembar kerja siswa, brosur, leaflet, wallchat, foto/gambar, model/maket.

b. Bahan ajar dengar (audio) atau program audio adalah semua sistem yang menggunakan sinyal radio secara langsung yang dapat dimainkan atau didengar oleh seseorang atau sekelompok orang. Contohnya kaset, radio, piringan hitam, dan compact disk audio.

c. Bahan ajar pandang dengar (audio visual) adalah segala sesuatu yang memungkinkan sinyal audio dapat dikombinasikan dengan gambar gerak secara sekuensial. Contohnya video compact disk dan film.

d. Bahan ajar interaktif (interactive teaching material) adalah kombinasi dari dua atau lebih media (audio, teks, grafik, gambar, animasi dan video) yang oleh penggunanya dimanipulasi atau diberiperlakuan untuk mengendalikan perintah dan/atau perilaku alami dari suatu presentasi. Contohnya compact disk (CD) interactive.

Multimedia interaktif adalah suatu multimedia yang dilengkapi dengan alat pengontrol yang dapat dioperasikan oleh pengguna, sehingga pengguna dapat memilih apa yang dikehendaki untuk proses selanjutnya. Contoh multimedia interaktif adalah pembelajaran interaktif, aplikasi game, dan lain-lain (Daryanto, 2013: 51). 
Menurut Wijayanto (2013: 11) Multimedia interaktif merupakan suatu media yang dapat digunakan sebagai bahan ajar dalam pembelajaran yang menggunakan berbagai jenis media yakni audio, video, grafis dan sebagainya yang mampu melibatkan banyak indra dan organ tubuh selama proses pembelajaran berlangsung dan terdapat suatu proses pemberdayaan siswa untuk mengendalikan lingkungan belajar.

Sedangkan Munir berpendapat bahwa Multimedia merupakan perpaduan antara media (format file) yang berupa teks, gambar (vektor atau bitmap), grafik sound, animasi, video, interaksi dan lain-lain yang telah dikemas menjadi file digital (komputerisasi), digunakan untuk menyampaikan pesan kepada publik. Sedangkan pengertian interaktif terkait dengan komunikasi dua arah atau lebih dari komponen-komponen komunikasi. Komponen komunikasi dalam multimedia interaktif adalah hubungan antara manusia sebagai user atau pengguna produk dan komputer sebagai software dalam format file tertentu yang biasanya dalam bentuk CD (Munir, 2013: 110).

Dengan demikian, maka Multimedia interaktif merupakan pembelajaran dengan menggunakan berbagai media yang dilengkapi dengan alat pengontrol yang dapat dioperasikan oleh pengguna dan pengguna dapat memilih pembelajaran apa yang dikehendakinya.

Karakteristik multimedia pembelajaran harus memiliki lebih dari satu media baik dalam bentuk audio, visual, dan audiovisual. Selain itu multimedia pembelajaran juga harus memiliki kekuatan variasi akan warna, dan resolusi objek agar dapat menarik kepekaan indra penglihatan dan harus bersifat interaktif diutamakan menggunakan tipe-tipe pembelajaran yang bervariasi, serta harus bersifat mandiri yang didalamnyamemberikan kemudahan dan kelengkapan sehingga dalammengukur proses dan hasil belajar.

Format sajian multimedia pembelajaran dikategorikan ke dalam lima kelompok, lebih jelasnya sebagai berikut (Daryanto, 2013: 54):

\section{a. Tutorial}

Format sajian ini merupakan multimedia pembelajaran yang dalam penyampaian materinya dilakukan secara tutorial. Sajian tutorial ini dilakukan oleh guru atau instruktur. Format sajian ini berisi dengan teks, gambar, baik diam atau bergerak, dan grafik.

Format ini terdapat beberapa pertanyaan atau tugas yaitu ketika pengguna sudah membaca, menginterprestasikan dan menyerap konsep. Setelah pengajuan pertanyaan akan dilihat respon dari pengguna ketika respon pengguna salah maka pengguna harus mengulang memahami konsep secara keseluruhan atau pada bagian tertentu saja. Pada bagian akhir pada format ini akan ada tes untuk mengukur tingkat pemahaman pengguna atas konsep atau materi yang disampaikan.

b. Drill dan Practice

Format ini dimaksudkan untuk melatih pengguna sehingga memiliki kemahiran di dalam suatu keterampilan atau memperkuat penguasaan terhadap suatu konsep. Format ini juga dilengkapi dengan pertanyaan dan biasanya ditampilkan dalam bentukacak. Pada setiap pertanyaan dilengkapi pula jawaban yang benar lengkap dengan penjelasannya, sehingga diharapkan pengguna juga dapat memahami suatu konsep tertentu. Pada format ini, pengguna juga dapat melihat skor atau nilai yang dia capai, sebagai indikator dalam memecahkan pertanyaan yang diajukan.

c. Simulasi

Format ini mencoba menyamai proses yang terjadi pada dunia nyata. Pada dasarnya format ini mencoba memberikan pengalaman masalah yang terjadi di dunia nyata untuk pengguna yang berhubungan dengan suatu resiko. Contohnya pada saat mensimulasikan menjalankan pesawat terbang pengguna dihadapkan pada situasi pesawat yang akan jatuh. 


\section{d. PercobaanatauEksperimen}

Format ini lebih mirip dengan format simulasi, tetapi format ini lebih ditujukan kepada hal-hal yang bersifat eksperimen, misalnya kegiatan yang ada di laboratorium IPA, biologi atau kimia. Format ini menyediakan bahan dan alat untuk pengguna. Pengguna dapat melakukan kegiatan eksperimen dan percobaan kemudian pengguna dapat mengembangkan eksperimen dan percobaan yang telah dialakukan. Hasil akhir dari format ini diharapkan pengguna dapat menjelaskan suatu konsep atau fenomena tertentu.

e. Permainan

Format ini disajikan tetap mengacu pada proses pembelajaran serta dengan multimedia berformat ini diharapkan terdapat proses pembelajaran sambil bermain. Sehingga, pengguna seolah-olah sedang bermain tetapi sesungguhnya sedang belajar.

Format ini menggunakan berbagai macam media yang dikenal dengan pembelajaran berbasis multimedia, format ini dapat dibuat dengan berbagai macam perangkat lunak yang dapat untuk mengolah teks, gambar, audio, dan video. Misalnya Macromedia Family (Flash, Freehand, Authorware, Dreamweaver).

Format multimedia yang digunakan oleh peneliti dalam penelitian ini adalah gabungan dari bentuk tutorial dan latihan. Dalam tutorial siswa akan mendapatkan penjelasan terkait materi pelajaran yang diperlukan dan latihan sebagai alat ukur dari pemahaman materi yang dipelajari oleh siswa.

Perangkat lunak Adobe Flash yang sebelumnya bernama "Macromedia Flash" merupakan software yang dulunya dikembangkan oleh Macromedia tetapi sekarang dikembangkan oleh Adobe System.

Adobe Flash CS6 merupakan salah satu software yang banyak digunakan oleh kebanyakan orang karena kemampuannya mengerjakan segala hal yang berkaitan dengan multimedia. Kinerja Flash dapat juga dikombinasikan dengan programprogram lain. Flash dapat diaplikasikan untuk pembuatan animasi kartun, animasi interaktif, efek-efek animasi, banner iklan, website, game, presentasi, dan sebagainya.

Menurut Djaali (2007: 121) minat adalah rasa lebih suka dan rasa ketertarikan pada suatu hal atau aktivitas tanpa ada yang menyuruh. Pernyataan tersebut mengidentifikasi bahwa orang yang berminat akan ada rasa tertarik, tertarik dalam hal tersebut merupakan wujud dari rasa senang pada sesuatu.

W.S. Winkel yang dikutip oleh Budiyarti bahwa minat diartikan sebagai kecenderungan subjek yang menetap untuk merasa tertarik pada bidang studi atau pokok bahasan tertentu dan merasa senang untuk mempelajari materi itu (Budiyarti, 2011: 9).

Jadi menurut pendapatnya, kecenderungan dan kesadaran subjek yang sudah menetap dalam dirinya akan menyebabkan timbulnya minat dan merasa senang mempelajari materi yang telah diberikan.

Menurut Syah (2009: 151)secara sederhana, minat (interst) berarti kecenderungan atau kegairahan yang tinggi atau keinginan yang besar terhadap sesuatu. Minat yang dipahami dan dipakai oleh orang selama ini dapat mempengaruhi kualitas pencapaian hasil belajar siswa dalam bidang studi tertentu. Pemusatan perhatian yang intensif terhadap materi itulah yang memungkinkan siswa tadi untuk belajar lebih giat, dan akhirnya mencapai prestasi yang diinginkan.

Dengan demikian minat adalah kecenderungan seseorang terhadap obyek atau sesuatu kegiatan yang digemari yang disertai dengan perasaan senang, dengan adanya perhatian dan keaktifan.

Menurut Richardson dalam Najichun \& Winarso (2017: 140) bahwa belajar berhubungan dengan perubahan tingkah laku seseorang terhadap suatu situasi tertentu yang disebabkan oleh pengalamannya secara berulang-ulang dalam situasi itu, dimana perubahan tingkah laku itu tidak dapat dijelaskan atau dasar kecenderungan respon pembawaan, 
kematangan atau keadaan-keadaan sesaat seseorang.

Sutikno (2008: 4) mengartikan belajar sebagai suatu proses atau usaha yang dilakukan oleh seseorang untuk memperoleh perubahan yang baru sebagai hasil pengalamannya sendiri dalam interaksi dengan lingkungannya. Sedangkan menurut Morgan sebagaimana yang dikutip olehSuprijono mengatakan learning is any relatively permanent change in behaviorthat is a result of past experience (belajar adalah perubahan perilaku yang bersifat permanen sebagai hasil dari pengalaman) (Suprijono, 2009: 9).

Dengan demikian belajar adalah suatu perubahan tingkah laku yang terjadi sebagai hasil dari pengalaman individu dalam berinteraksi dengan lingkungannya. Jadi pengertian minat belajar adalah suatu proses usaha yang dilakukan seseorang dengan didasari perasaan senang untuk memperoleh suatu perubahan tingkah laku, sebagai hasil pengalamannya sendiri dalam berinteraksi dengan lingkungannya. Minat sangat erat kaitannya dengan kegiatan belajar, karena tanpa adanya minat, maka kegiatan proses belajar tidak akan berjalan dengan baik dan pada akhirnya keberhasilan dalam proses belajar tidak bisa mencapai hasil yang maksimal.

Minat yang timbul dalam diri seseorang dipengaruhi oleh banyak faktor, Sumadi Suryabrata dalam bukunya membagi faktor-faktor yang mempengaruhi minat belajar menjadi dua, yaitu faktor yang datang dari dalam dan faktor yang datang dari luar. Faktor dari dalam (intern) terdiri dua faktor yaitu psikologi dan fisiologi. Sedangkan faktor yang dari luar (ekstern) terdiri dari faktor non-sosial dan sosial. (Sumadi, 1998: 233)

Besar kecilnya minat seseorang pada sesuatu dapat dipengaruhi oleh beberapa hal seperti siswa itu sendiri, lingkungan yang mendukung, faktor guru, dan keluarga. Menurut Reber yang dikutip oleh Syah (2008: 136) minat tidak termasuk istilah popular dalam psikologi karena ketergantungannya yang banyak pada faktor-faktor internal lainnya seperti: pemusatan perhatian, keingintahuan, motivasi, dan kebutuhan.

\section{METODOLOGI PENELITIAN}

Jenis penelitian yang digunakan yaitu penelitian dan pengembangan Research and Development (R\&D). Metode penelitian dan pengembangan ialah metode penelitian yang digunakan untuk menghasilkan produk tertentu, dan menguji keefektifan produk tersebut (Sugiyono, 2009: 107).

Penelitian ini menggunakan model penelitian yang diadaptasi dari model pengembangan ADDIE (Analysis, Design, Develop, Implement, dan Evaluate). Model ADDIE mulai ada pada tahun 1990-an yang dikembangkan oleh Dick dan Carry yang digunakan untuk merancang sistem pembelajaran (Mulyatiningsih, 2012: 200). Selain itu model ini dapat digunakan untuk berbagai macam bentuk pengembangan produk seperti model, strategi pembelajaran, metode pembelajaran, media dan bahan ajar. Model ini menggunakan 5 tahap yaitu tahap Analysis, Design, Development, Implementation, and Evalution.

Teknik pengumpulan data yang digunakan untuk menghimpun data selama proses pengembangan bahan ajar berbasis multimedia interaktif yaitu menggunakan teknik observasi dan angket. Teknik observasi yang dilakukan adalah observasi tidak terstruktur. Menurut Sugiyono (2009: 205) observasi tidak terstruktur adalah jenis kegiatan observasi tanpa persiapan secara sistematis tentang apa yang akan dilakukan peneliti.

Menurut Sugiyono (2009: 199) angket adalah teknik pengumpulan data dengan cara memberikan beberapa pertanyaan atau pernyataan tertulis kepada responden. Angket akan diberikan kepada siswa untuk mengetahui tingkat minat sebelum dan sesudah pembelajaran menggunakan bahan ajar berbasis multimedia interaktif.

\section{HASIL DAN PEMBAHASAN}

Dari hasil pengamatan dapat diketahui bahwa guru cenderung hanya menggunakan bahan ajar cetak seperti LKS dan buku paket sehingga membuat siswa kurang antusias dan merasa bosan saat 
mengikuti pembelajaran. Siswa akan lebih termotivasi, fokus dan mandiri apabila metode pembelajaran yang inovatif, bahan ajar variatif dan pembelajaran dilaksanakan dengan menarik dengan cara memanfaatkan fasilitas yang sudah disediakan sekolah.

Setelah mengetahui permasalahan yang dihadapi siswa dan potensi yang ada, peneliti melakukan diskusi dengan guru terkait mata pelajaran dan standar kompetensi yang akan diambil sebagai bahan materi pada Bahan Ajar Matematika Berbasis Multimedia Interaktif.

Produk akhir penelitian pengembangan (research and development) adalah bahan ajar berbasis multimedia interaktif yang dapat digunakanan untuk mendukung pembelajaran mata pelajaran matematika kelas VIII. Pembuatan bahan ajar multimedia interaktif ini melalui beberapa tahap diantaranya: 1) analisis (Analysis), 2) desain (Design), 3) pengembangan (Development), 4) implementasi (Implementation), 5) evaluasi (Evaluation).

Bahan ajar multimedia interaktif dapat digunakan dalam pembelajaran di dalam kelas maupun belajar mandiri. Produk bahan ajar multimedia interaktif dapat digunakan dengan mudah karena dilengkapi dengan panduan penggunaan. Bahan ajar multimedia interaktif menggunakan materi pokok kubus dan balok yang disesuaikan dengan silabus KTSP kelas VIII. Bahan ajar ini berisikan materi yang dilengkapi dengan quiz yang disajikan sedemikian rupa sehingga membantu peserta didik dalam memahami pembelajaran.

Bahan ajar multimedia interaktif telah memenuhi kriteria kelayakan baik penilaian materi maupun media. Pada penilaian materi dilakukan oleh ahli materi yang terdiri dari Dosen IAIN Syekh Nurjati Cirebon dan Guru mata pelajaran matematika SMP N 12 Kota Cirebon, indikator yang dinyatakan Sangat Baik adalah indikator kesesuaian dengan kurikulum, indikator kesesuaian penggunaan bahasa dan indikator penggunaan bahan ajar, sedangkan indikator yang dinyatakan Baik adalah indikator penyajian tiap komponen materi dan indikator penyajian interaksi. Pada penilaian media dilakukan oleh ahli media yang terdiri dari Dosen IAIN Syekh Nurjati Cirebon dan Guru mata pelajaran TIK SMP N 12 Kota Cirebon, indikator yang dinyatakan Sangat Baik adalah indikator kemudahan penggunaan dan indikator audio, sedangkan indikator yang dinyatakan Baik adalah indikator sederhana \& memikat dan indikator visual.

Selain penilaian ahli dari ahli materi dan ahli media penilaian juga dilakukan oleh peserta didik dalam menentukan kelayakan bahan ajar multimedia interaktif. Berdasarkan penilaian peserta didik uji kelompok kecil indikator yang dinyatakan Sangat Baik adalah indikator kemudahan memahami materi dan ketepatan penggunaan bahasa, kemudian indikator yang dinyatakan Baik adalah insikator kejelasan teks, indikator penggunaan bahan ajar, indikator ketepatan sistematika penyajian materi, indikator kesesuaian soal dengan materi, indikator ketepatan audio dan indikator peningkatan motivasi dan daya tarik, kemudian indikator yang dinyatakan Cukup adalah indikator kesesuaian gambar dan animasi dan indikator kemudahan belajar. Selanjutnya berdasarkan penilaian peserta didik uji coba kelompok besar (lapangan) indikator yang dinyatakn Baik adalah indikator kejelasan teks, indikator kesesuaian gambar dan animasi, indikator penggunaan bahan ajar, indikator kemudahan memahami materi, indikator ketepatan sistematika penyajian materi, indikator ketepatan penggunaan bahasa, indikator ketepatan audio dan indikator keningkatan motivasi dan daya tarik, kemudian indikator yang dinyatakan Cukup adalah indikator kesesuaian soal dengan materi dan indikator kemudahan belajar.

Data penilaian selanjutnya dihitung reratanya. Dari hasil rerata masing-masing penilaian akan dikategorikan berdasarkan lima tingkatan yang telah ditetapkan sebelumnya. Data hasil penilaian adalah sebagai berikut: (1) validasi ahli materi memperoleh skor 4,2 termasuk dalam kategori Baik, (2) validasi ahli media 
memperoleh skor 4,26 termasuk dalam kategori Sangat Baik, (3) respon peserta didik pada uji coba kelompok kecil memperoleh skor 3,75 termasuk dalam kategori Baik, (4) respon peserta didik pada uji coba kelompok besar memperoleh skor 4,26 termasuk dalam kategori Sangat Baik. Sehingga dapat disimpulkan bahwa bahan ajar multimedia interaktif dari segi materi dan media Layak digunakan sebagai bahan ajar dan baik dalam proses pembelajaran.

Penelitian ini tidak hanya sebatas mengukur validitas bahan ajar multimedia interaktif kubus dan balok saja tetapi juga mengukur tingkat minat belajar peserta didik dalam belajar matematika sebelum dan sesudah mengikuti pembelajaran menggunakan bahan ajar multimedia interaktif kubus dan balok. Hasil minat belajar awal peserta didik memperoleh skor total2126, hasil minat belajar akhir memperoleh skor total2521 jadi N-gain dari minat belajar siswa diperoleh sebesar 0,405. Dengan demikian minat peserta didik meningkat dengan kategori peningkatan sedang.

Hal ini sesuai dengan pendapat Hamalik (2006: 34)yang menyebutkan bahwa salah satu faktor yang mempengaruhi minat adalah bahan pelajaran \& sikap guru, bahan pelajaran yang menarik akan sering dipelajari oleh siswa yang bersangkutan. Selain itu menurut Wijayanto (2013: 113) salah satu kelebihan menggunakan multimedia interaktif dalam pembelajaran adalah dapat menambah motivasi peserta didik selama proses belajar hingga didapat tujuan pembelajaran yang dinginkan. Motivasi menurut Hamalik (2006: 34) juga merupakan salah satu faktor yang mempengaruhi minat, siswa akan memiliki minat yang tinggi jika memiliki motivasi. Seseorang akan dikatakan memiliki motivasi belajar jika telah memiliki niat yang tinggi untuk mempelajari suatu mata pelajaran, makan akan mempelajarinya dalam jangka waktu tertentu.

Berdasarkan pembahasan di atas dapat disimpulkan bahwa penelitian ini mendapat respon baik dari guru mata pelajaran maupun dari siswa, dengan hasil penilaian yang menyatakan bahan ajar multimedia interaktif kubus dan balok layak dan baik digunakan dalam proses pembelajaran, serta bahan ajar berbasis multimedia interaktif dapat meningkatkan minat belajar peserta didik.

Berdasarkan hasil pengembangan bahan ajar yang dilakukan peneliti terdapat beberapa perbedaan dengan bahan ajar sebelumnya antara lain yaitu bahasa yang dikemas dalam bahan ajar multimedia interaktif ini lebih sederhana dan sesuai dengan tingkat perkembangan intelektual siswa sehingga bahasa yang digunakan mudah dipahami, selain itu dalam bahan ajar multimedia interaktif ini memuat animasi jaring-jaring kubus dan balok sehingga mempermudah siswa untuk memahami materi jaring-jaring kubus dan balok. Lebih lanjut lagi bahan ajar multimedia interaktif juga memuat quiz yang lebih menarik dan menyenangkan dengan menampilan langsung hasil yang diperoleh siswa, jadi siswa yang merasa nilainya kurang bisa mengulangi kembali quiznya sampai mendapatkan nilai yang ditentukan.

Selain dari beberapa perbedaan bahan ajar multimedia interaktif dengan bahan ajar sebelumnya di atas, terdapat juga kekurangannya yaitu bahan ajar multimedia inteeraktif hanya bisa digunakan menggunakan perangkat komputer atau laptop, sedangakan tidak semua siswa memiliki komputer atau laptop di rumahnya. Namun demikian, bahan ajar multimedia interaktif lebih memberi dampak positif terhadap minat belajar matematika siswa.

Keterbatasan bahan ajar multimedia interaktif kubus dan balok berdasarkan penelitian dan pengembangan yang telah dilakukan adalah :

1. Produkbahan ajar multimedia interaktif yang dihasilkan hanya menyampaikan pada Kompetensi Dasar 5.1 Mengidentifikasi sifat-sifat kubus, balok, prisma, dan limas serta bagianbagiannya, 5.2 Membuat jaring-jaring kubus, balok, prisma dan limas, 5.3 Menghitung luas permukaan dan volume kubus, balok, prisma dan limas.

2. Siswa hanya menggunakan bahan ajar multimedia interaktif saat jam 
pelajaran matematika dan ketika lab. Komputer kosong.

3. Uji coba produk hanya dilakukan dua kali, uji coba kelompok kecil di kelas VIII Adengan jumlah 5 peserta didik dan uji coba lapangan (uji coba kelompok besar) di kelas VIII B dengan jumlah 32 peserta didik.

4. Uji coba terhadap bahan ajar multimedia interaktif hanya dilakukan di satu sekolah saja karena keterbatasan waktu dan biaya.

5. Penelitian dan pengembangan ini hanya memunculkan manfaat penggunaan bahan ajar terkait dengan peningkatan minat belajar matematika siswa.

\section{KESIMPULAN DAN SARAN}

Kesimpulan

Validitas bahan ajar multimedia interaktif kubus dan balok berdasarkan penilaian ahli materi mendapat nilai ratarata 4,2 dengan kategori Baik, berdasarkan penilaian ahli media mendapatkan nilai rata-rata 4,26 dengan kategori Sangat Baik, berdasarkan respon siswa uji kelompok kecil mendapat nilai rata-rata 3,75 dengan kategori Baik, dan berdasarkan respon siswa uji kelompok besar medapat nilai rata-rata 4,26 dengan kategori Sangat Baik. Berdasarkan penilaian ini, bahan ajar berbasis multimedia interaktif kubus dan balok Layak digunakan sebagai bahan ajar matematika di SMP kelas VIII.

Bahan ajar berbasis multimedia interaktif kubus dan balok yang dikembangkan dapat meningkatkan minat belajar matematika siswa dengan $\mathrm{N}$-gain yang diperoleh sebesar 0,405 yang termasuk dalam kriteria Sedang. Minat belajar awal diperoleh skor total 2026 sedangkan minat belajar akhir diperoleh skor total 2521 .

Saran

Guru diharapkan mampu menjadikan bahan ajar multimedia intraktif sebagai salah satu alternatif bahan ajar pada mata pelajaran matematika yang mampu membuat siswa menjadi berminat dan lebih aktif dalam pembelajaran.Siswa diharapkan dapat menggunakan bahan ajar multimedia interaktif ini saat di rumah atau di kelas, karena itu akan sangat membantu siswa ketika belum memahami materi yang dipelajari.Materi yang digunakan sebaiknya lebih luas, tidak hanya satu kompetensi dasar dan produk bahan ajar multimedia interaktif tidak hanya diujicobakan pada satu sekolah sehingga dapat digunakan lebih luas dan dihasilkan produk yang baik.

\section{DAFTAR PUSTAKA}

Budiyarti, Y. (2011). Minat Belajar Siswa Terhadap Mata Pelajaran Bahasa Indonesia (studi kasus di SMA PGRI 56 Ciputat)(Doctoral dissertation, UIN Syarif

Hidayatullah).http://repository.uinjkt. ac.id/dspace/bitstream/123456789/279 7/1/YETI\%20BUDIYARTI-FITK.pdf

Daryanto. (2013). Media Pembelajaran. Yogyakarta: Gava Media.

Depdiknas. (2007). Kajian Kebijakan Kurikulum Mata Pelajaran Matematika. Jakarta: Balai Pustaka.

Hamalik, O. (2006). Manajemen Pengembangan Kurikulum. Bandung: Remaja Rosdakarya.

H Djaali, D. (2007). Psikologi pendidikan. Jakarta: Bumi Aksara

Lestari, I. (2013). Pengembangan Bahan Ajar Berbasis Kompetensi. Padang: Akademia Permata

Majid, A. (2009). Perencanaan pembelajaran Mengembangkan Standar Kompetensi Guru. Bandung: PT. Remaja Rosdakarya.)

Mulyatiningsih, E. (2012). Metoode Penelitian Terapan Bidang Pendidikan. Bandung: Alfabeta.

Munir. (2013). Multimedia Konsep \& Aplikasi dalam Pendidikan. Bandung: Alfabeta.

Najichun, M., \& Winarso, W. (2017). HUBUNGAN PERSEPSI SISWA TENTANG GURU MATEMATIKA DENGAN HASIL BELAJAR MATEMATIKA SISWA. Jurnal Psikologi Undip, 15(2). 139-146

Prastowo, A. (2014). Pengembangan Bahan Ajar Tematik. Jakarta: Kencana

Raharjo, H. (2014). Pengembangan bahan ajar berbasis komputer dalam pembelajaran matematika pada pokok bahasan kubus dan balok. EDUMA: 
Mathematics Education Learning and Teaching, 3(2). 119-132.)

Sugiyono. (2009). Metode Penelitian Kuantitatif, Kualitatif, dan $R \& D$. Bandung: Alfabeta

Sumadi, S. (1998). Psikologi Pendidikan. Jakarta: PT. Raja Grafindo Persada

Suprijono, A. (2009). Cooperative Learning Teori \& Aplikasi PAIKEM. Yogyakarta: Pustaka Pelajar

Sutikno, S. (2008). Belajar dan Pembelajaran. Bandung: Prospect.

Syah, M. (2008). Psikologi Pendidikan. Bandung: PT Remaja Rosdakarya
Syah, M. (2009). Psikologi Belajar. Bandung: Raja Grafindo Persada.)

Wijayanto, H. (2013). Pengembangan Media Pembelajaran Matematika Berbasis Multimedia Interaktif Menggunakan Adobe Flash CS3 Profesional Dengan Pendekatan Terbimbing Pada Pokok Bahasan Teorema Pythagoras. (Doctoral dissertation, UIN Sunan Kalijaga).http://digilib.uin-

suka.ac.id/9048/1/BAB\%20I, \%20V,\%2 0DAFTAR\%20PUSTAKA.pdf 